\title{
Comedy of commerce: Towards a wonderful exchange in land reform?
}

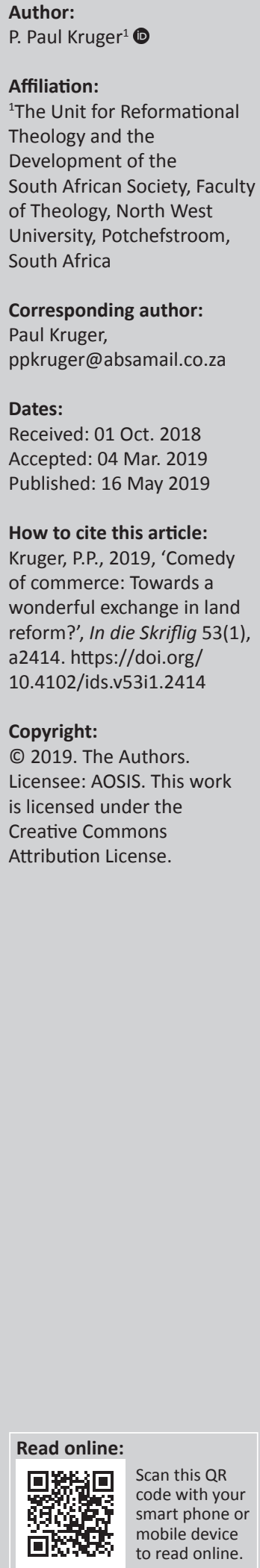

This article theologically explores the controversial issue of land reform, especially in South Africa, by probing a theatrical metaphoric framework - with its depth and holism. This will be done in order to articulate the deep Christian confessional notion of sanctorum communio [communion of the saints], having the unfathomable notion of admirabile commercium [wonderful commerce or exchange] at the centre of its twofold sense (communion of the sancta and sancti) as an alternative possibility acted out on a civil play stage (or in a public dramatic amphitheatre) of land reform that might be seen to be 'performed' in South Africa today. As deepest background to all problems of land greed and land stinginess, Christ's short 'parabolic play' of the Rich Fool is brought into focus. The inquiry argues that the 'wonderful exchange' acted out in its inner and outer commerce with the sancta [Christ as the Fruit of the land and his gracious benefits of land-giving and land-flourishing] and circling out into the sancti [the commerce of the ecclesiastical, 'theatrical company' of people in freedom, equality and brotherhood] should, prompted by the Holy Spirit (also in his cosmic inhabitation), decentralise this 'comedy of commerce' further into public, civil communities or 'companies' of people-and-land, permeated by this commerce's play of freedom, equality and brotherhood.

Keywords: Communio sanctorum; Land reform; Theodrama; Mirifica commutation; Fruit of the land.

\section{Introduction}

\section{Theme and outline}

The theme of this discourse, theodramatically ${ }^{1}$ addresses the issue of land reform (including the possible expropriation with or without compensation) in as far as land commerce, especially in South Africa might be impacted by the age-old Christian notion of a wonderful commerce or joyful exchange, articulated - metaphorically speaking - in the perspective of a 'community theatre' (Horton 2011:32, [author's own italics]) or, in extreme form, as an 'interactive theatre of resident aliens and holy fools' (Vanhoozer 2014:179, [author's own italics]). In this enterprise, we concur with the ethical theologian, Davis (2009:204), who refers to the relevancy - specifically concerning land, food and agriculture issues - of the 'beautiful image' of Psalm 36:9: 'For with you is the fountain of life; in your light we see light.' Moltmann (1991:295) commented that 'This divine fountain of light enlightens the whole creation, in order that we might see in his light what the things are and who we in truth are'. Therefore, we contend that land distribution 'in thy light' should also be approached as 'a genuinely theological topic' (cf. Davis 2009:204). Furthermore, 'the nature of land as gift in a theological context' (Mei 2009:451, [author's own italics]) has to be inculcated.

'The church happens in the unio mystica' (Beker \& Hasselaar 1990:50). Taking our cue from this characterisation of the church (cf. also Berkouwer 1970:18; Heidelberg Catechism (HC) 21:54 - the church is what Christ does through his Word and Spirit), we will contend in the following discourse that this happening or event of unio mystica [mystic union] - the core of which is formed by the mystery of a 'wonderful exchange' - is dynamically and dramatically through faith improvised in the continuous enactment of the various 'scenes' of its encompassing action, the sanctorum communion. The remarkable fact emerges that the 'mystical heart' of the happening or 'drama', which is church ('drama' derives from Greek dra-ein, meaning 'to do'), is expressed by means of the economic term commercium. This ordinary, mercantile, transactional word (commercium in Latin derives from cum added to merx, as related to 'merchandise') plays a challenging role in the investigation. The transversal movement of sacred commerce and 'secular' land commerce in a dramatic context might, indeed, prevent a reductionist foreclosing of both aspects (cf. Bakker 1978:179). 
Outlining the research, it must be stated that this Christian comedy of land commerce will focus, firstly, on land tenure in a 'tragic' perspective; secondly, on land reform in a theodramatic, 'comic' perspective; thirdly, on land reform seen through the lens of 'comedy' as twofold 'doing' of communio sanctorum; and finally, on some concluding viewpoints.

\section{Land tenure in a 'tragic' perspective A contemporary multi-performance theatre of land reform}

Present-day South Africa seems to display many strands of a grotesque carnival (cf. Eco 2007:76), even of a 'theatre of the absurd' with contesting and clashing 'performances' (cf. Van Onselen 2015:16) frequently 'clouded by misrepresentation and lack of data' (Cousins \& Hall 2018:1). In South Africa, with its past characterised by 'extreme dispossession through colonialism and apartheid' (Cousins \& Hall 2017:1), the image of public space as a theatre of the absurd is par excellence applicable to rivalling narratives concerning land commerce. Apparently, a 'crippling effect', driven by the 'fear of the judgment of tomorrow' on the failures of yesterday (cf. Knott 2015:111), habitually retards debates about equitable land reform. This 'lameness' might lose its sting when life is rendered as 'a play within the play, carried forward by amor mundi' (Knott 2015:111). The fear of future retaliation seems to be akin to the 'two dimensions' of anxiety diagnosed by Zizek (2017:169-170): firstly, an 'atmosphere of fear ...', (characterised by) 'the suspicious gaze', which detects racism (white or anti-white) or colonialist traits in the other; and secondly, a lingering anxiety among former privileged groups, manifesting itself in 'the tragicomic spectacle of endless self-culpabilization' (Zizek 2017:170).

Undoubtedly, we must accept corporate responsibility for the tragic fact that the 1913 Land Act was the most visible manifestation of colonial conquest, as it formalised dispossession' (Ngcukaitobi 2018:272; cf. also Changuion \& Steenkamp 2012:130-149 for an overview of the 1913 Land Act). According to Terreblanche (2014:509-506), no quest for reparative and distributive justice can proceed truthfully without Western nations showing due remorse for the evil of enriching themselves through imperialism and colonialism - also in South Africa 'over a period of 500 years ... until now'. With good reason, he (Terreblanche 2014:509-510) adds that 'the Western empires - and especially the British and Americans - have not even been prepared to acknowledge explicitly the damage their imperial endeavours have brought about in the Western world'. In addition, it must be acknowledged in truthfulness that the policy of Apartheid in South Africa was rightly named in the United Nations Resolution of 1973 as a 'crime against humanity', not in the last instance because of its policy of discrimination concerning land.

Whereas this investigation is aimed at a theological approach to land reform, it might be sufficient in this regard to state that in the late years of the 21st century's second decade, a 'fight rages over land reform in South Africa' (Montanari 2018:1), especially in view of a probable expropriation of land without compensation. However, a theological investigation must attend the deepest problem in this 'raging fight'. Accordingly, the harsh reality (not a fiction) of such an existing, concrete, lived, agonistic world as this is exposed through the metaphorical lens of a parable or a 'theatrical play in a nutshell ... a dramatization (of) the fundamental choice people should make in their lives: between the winning or losing of their existence' (Veltkamp 1988:182, [author's own italics]). In this way - and also in the subsequent exploration - a mere factual, descriptive rendering of the problematic surrounding land reform is transcended.

\section{A parable of 'tragic' land commerce: The 'Rich Fool'}

A creed of greed (cf. Brueggemann 1989:106) was lifedestroying for the actor of covetousness in our Lord Christ's parable of the Rich Fool (Lk 12:13-21). Without confessing that the land and the crops were God's property ('my crops') and reasoning in a circle around himself, the farmer blatantly neglected the wisdom of Proverbs 11:26 that the hoarding of grain calls forth curses, 'but blessing crowns him who is willing to sell'. Versteeg (1987:51) is of the opinion that the farmer apparently intended to manipulate the market by not selling; thus creating scarcity that helped to increase the price of grain exorbitantly. If this interpretation is correct, it preempts the contemporary understanding of the market that has scarcity as its driving force: 'In other words, hunger is written into the conditions under which economics (also land economics!) operates' (Cavanaugh 2008:90).

It must be emphasised that the protagonist of Jesus' parable represents both the avaricious man who desired land and his refusing brother. Every addressee of this parabolic play or 'game' (cf. Moltmann 2000:164) of our Lord is challenged to detect and address his or her own form of masked greed. Both 'sides' in the debate should seriously heed what Calvin says so incisively in his comments on Habakkuk 2:5, 6 (where desperate cries are raised against that kind of plunderer who shows himself to be 'as greedy as the grave and, like death, is never satisfied ... who makes himself wealthy by distortion'): 'It is then the same as though God heard himself, when he hears the cries and groanings of those who cannot bear injustice' (as quoted by Wolterstorff 2011:119). In the disturbing realisation that 'to inflict injury on a fellow human is to wound God' (Wolterstorff 2011:119), nobody can feel comfortable about the legacy of socio-economic injustice which was inherited from the Natives Land Act of 1913 (and) continues to haunt the majority of black South Africans' (Modise \& Mtshiselwa 2013:20).

\section{Land reform in a theodramatic, 'comic' perspective Depth dimension}

With good reason, it is contended that 'a theology of our time should help us to know that Being is indeed the theatre of 
God's glory' (Robinson 2016:147). This appears to be especially true regarding the 'loss of community in the age of nihilism' (Goosen 2009:7), including land dwellers' community with each other and with the land itself and its fruit. Whereas immanent reality, through its dramatic correlation with transcendence, traditionally 'resonated the depth and mystery' sounding forth from the latter, in modernity, autonomous, one-dimensional man only meets himself and his 'unbearable lightness' echoing in his 'things' (such as land) (cf. Goosen 2009:53, 359). In an anti-dramatic, reductionist reality, things and places lose their 'personal dimension' and become, as it were, warzones of cold, abstract and geometrically disposable commodities in which the 'logic of the strongest' prevails (cf. Goosen 2015:414). A Christian dramatic approach, however, is different:

Whenever the speaker (or thinker), not merely stays with the superficial but dares to descend into the depths, he comes, as it were, face to face before a (Trinitarian ) Person vis-à-vis creation as well as salvation and sanctification. (Bavinck 1961:38-39)

This Trinitarian possibility of a face-to-face depth encounterthrough the dramatic lens of 'facing each other ... (and) facing the earth' (Scruton 2014:97, 115) - makes it preferable to speak of 'deep comedy'2 as Leithart (2006:115) advocates. It does not denote an abstract 'world-view', but 'worked out in the joyful life of the Christian church, deep comedy is the chief weapon of our warfare' (Leithart 2006:147). In this sense, Horton (2011:19) can speak of a Christian 'counterdrama' and -a 'deep comedy' that counteracts every shallow, mere phenomenal tragicomedies as well as particularly hurtful tragedies of secular land reform with their disrupting, deadly and murderous effects - nearly resembling the inexorable fatum of Greek tragedies (cf. also the 'death drive' apparent in the parable discussed above). This does not suggest that our current involvement 'in the delight of the drama' of Christian communion (cf. Brueggemann 1993:114) or hope-filled Christian comedy in any way can exclude or ignore the 'tragic' aspects of land hunger. Who would not be moved by the tears of the Portuguese colonialist chronicler, Zurara, as he described the piteous sight and unspeakable agony of black slave-bodies been torn from the African land to which they belonged and then cruelly auctioned at a black West-African slave market by the illustrious Christian, Prince Henry the Navigator, in the year 1444 (Jennings 2010:15-24)? We are not in the least contending for a kind of Christian comedy that the church literally should stage as a 'makebelieve fictionality of "as if"' (cf. the 'Als-ob'-philosophy of Vaihinger as Berkouwer 1949:39 references it). To the contrary, we are arguing for the reality of embodied faith and the reality of embodied Kingdom - citizenship, articulated not in propositional, logical-deductive form, but viewed through the metaphorical lens of 'a drama of living with Jesus'. This dramatic perspective thus discloses an 'ongoing improvisation in the Spirit' based on a biblical 'script' (for argument's sake, a 'script' such as St. John's Gospel, which is 'perhaps the most dramatic book of the New Testament' - cf. Ford 2014:1, 20). In short, exactly at that point to which the 2.Compare Dante's use of 'comedy' in his Divine Comedy (1300). whole gospel's rendering of the reality of Jesus' life, death and resurrection was moving (Jn 20:19-23), namely the Spiritinbreathing into the church by the main Character, the resurrected Crucified it is suggested that 'things can still go terribly wrong' and that forgiveness is always needed in the continuing dramatic happening of this reality (Ford 2011:33, [author's emphasis]).

\section{Holistic dimension}

To a catholic-reformed style of theology such a 'the odramatic' approach would not be implausible. Bavinck convincingly points out how Calvin - more than Rome and the other magisterial Reformers - articulates God's re-creation (cf. Conradie 2013:52-119) as 'the good news of renewal for all creatures [where] the Gospel comes to its full validity, to veritable catholicity' (Bavinck 1968:23-24). Following in Calvin's footsteps, a form of catholicity with 'its perspective on the whole in its qualitative wealth' (Berkouwer 1970:147) might today be combined with the 'organising metaphor' of the Reformer's whole thinking, namely the dramatic (Lane 2011:59; cf. also the next paragraph). At least the following two sides of catholicity in this rich, holistic perspective are reinforced by the metaphor of drama.

Firstly, reinforcing its catholicity in time, the theatrical metaphor 'has a long and distinguished career in theology' (Horton 2002:243). Later, significantly, Calvin's special provenance for the metaphor of the cosmos as theatre (cf. Piper \& Mathis 2010:passim) involved all creation in the act of performance' (Lane 2011:68, [author's own italics]). Accentuating the role that the metaphor of theatre plays in Calvin's theology does in no way imply that it overshadows or replaces other important analogies characteristic of his thinking, for example, the image of 'mirror', used 'to circumscribe ... forms of accommodation' (Van der Kooi 2002:58-59), the analogy of 'glasses' (Calvin 1962a; Inst. 1.6.1), and the metaphor of 'fountain' (Gerrish 1993:26). Yet, according to Calvin-expert, Wencelius (quoted by Rijnsdorp 1954:29), the Genevan had 'au plus haut point le sens du drame' [an extremely important sense of drama]. Strangely, it seems as if Calvin's 'positive' theological employment of theatrical symbolism comes as an unpleasant surprise to many Calvinists (according to Selderhuis 2000:305, who cites eight references to theatrical metaphoric in some of the Reformer's commentaries on the Psalms alone). Battles (1984:36, [author's own italics]) claims that Calvin chose theatre 'as his ruling metaphor':

The Institutes is constructed backward from the incarnation, through the law, the fall to the creation, from the second Adam to the first Adam. The theater [sic] is built, the stage set, wherein the audience, inexcusable in its blindness, may at last view its true destiny in Christ. Step by step, calculated to our capacity, God moves the drama forward to its heavenly denouement. (Battles 1984:37)

Secondly, reinforcing reformed catholicity as complexio oppositorum (Berkhof 1959:216), we distinguish with Hegel (1973:149) dramatic conceptuality in such a way that it forms a 'conciliatory union' between the epic as the 'objective', 
logical and analytical monologue type of discourse and the lyric as the 'subjective', emotional and poetical (Vanhoozer 2005:84-95). Dramatic metaphoric, argues Ford (2011:66) with good reason, presents an apt way of understanding Scripture, theologising and living as well as the interaction between faith and secularity, and even leads to Ford (2011:66) attempting to 'distil a "double helix" of cries' (including doxology, Christology, pneumatology, the Kingdom, and wisdom) in order to establish 'a generative "dramatic code" for this century's theological thinking'.

To summarise: the advantage of viewing land reform in South Africa through the lens of various 'performances' (Van Onselen 2015) is that the land policies, land ideologies or theories of land appropriation and land retaining are not caught in binary, often sterile and antithetical thinking or sloganizing. Instead the debating of these issues can be 'triangulated' (cf. Buitendag 2009:220-221 for a particularly creative theological employment of this notion) into a mode (dramatic) that tests the various conceptualities as to their enactable potential. Far from forcing the land debate into a 'straitjacket of drama', the mere cognitive verbalism of many prevalent discussions is rather broadened out to 'do unto others what you want them to do unto you' (including doing good to the 'the ecological other' of the soil).

\section{Land reform seen through the lens of 'comedy' as twofold 'doing' of communio sanctorum}

\section{Sanctorum communio: Sancti and sancta}

This 'communion of the saints' (communio sanctorum) includes both the sancti as holy persons and the sancta as holy things (Van Ruler 1969:145-147). One may concur with the comments of Barth (1964:87) on the HC (21.55) in the sense that sancta is discussed in the first section ('first, that all and everyone who believes, being members of Christ, are in common partakers of Him, and of all his riches and gifts'). Christ, himself, is God's 'indescribable gift' (2 Cor 9:15) and 'along with Him', all things are graciously given to us $(\mathrm{Rm} 8: 32)$. God shows his love as Creator in that he upholds his right over all creatures. In Christ, however, 'He also graciously brings them home and preserves them' (Käsemann 1980:247, [author's emphasis]). In this Christ, every believer and all believers together, participate. It is this first section (HC 21.55a, comprising the sancta) that will form the basis of our current paragraph's scrutiny. This paragraph will, therefore, attempt to throw light on the theodramatic enacting of deep sharing as concentrating firstly (christologically focused) on Christ as the Gift of Fruit and First Fruit of the land.

Later, our focus will shift to the relation of this communion drama to the second section (HC 21.55b, dealing with the sancti). From a primarily pneumatological vantage-point, the focus will then fall on 'the sancti' as cruciform company of the new creation's (including the land's) first fruits.

\section{Comedy of the sancta}

\section{The inner drama: Unio mystica}

Before the 'external drama' of Holy Communion as one of the church's means of grace is discussed with respect to its sharing in the sancta, the inner drama of sharing in this sancta, namely the unio mystica, should receive attention first. For our quest, it is important that the hidden unio mystica between Christ and believers serves as 'a prism' for Calvin's whole theology (Van 't Spijker 1995:60). It was in his famous letter to Vermigli that Calvin (1962a) described this communion concisely as being:

\begin{abstract}
... that holy union through which the Son of God takes us up in his body to share everything that belongs to him with us, so we create our life from his flesh and blood, so that He might without injustice be called our food. (p. 1555)
\end{abstract}

Starting with Luther's 'inner drama' at the core of his rediscovered faith dynamic, one could venture to say that a dramatic vein runs through reformed theology after the Reformation era; yet, it has nearly vanished in modernity (cf. Hobson 2009:83-86, 95). Within reformed theology, the inner drama seems to present itself especially dense where the unio mystica between Christ and Christians is concerned. The form it takes is that of the 'joyous exchange' (fröhliche Wechsel) in Luther's thinking (cf. Jüngel 1988:62-87 for an extensive discussion of this theologoumenon) and the 'wonderful exchange' (admirabile commercium) in Calvin's thinking:

Having become with us the Son of Man, he has made us with himself sons of God ... Having undertaken our weakness, he has made us strong. Having submitted to our poverty, he has transferred to us his riches ... (Inst. 4.17.2)

In the language of exchange (gift-giving and gift-receiving), an inner 'dramatic' movement is suggested in which the mystery of the communion is enacted between him, who, among all his other glorious epithets, is also the Lord of the land and us. This exchange is performed, as it were 'from face to face' (cf. 2 Cor 4:6; also Inst. 1.1.1 where man is pictured as being face to face with God). Christ, in a gracious action of commerce, gives himself and his riches through the Holy Spirit to us in order that, through the same Spirit, we might freely give our poverty, greed, weakness, perplexity, et cetera to him. In the hidden enactment of this exchange, we are, 'as it were, from moment to moment encouraged to dare living with this God' (Bakker 1978:37). Indeed, we were 'baptized ... into a life of (enacting) communion' (Torrance 1996:67).

Theodramatically parsed, such inner communing with the Lord of the land also includes a life exchange with him as the 'Fruit of the land' (New International Version; cf. also English Standard Version) or the 'Fruit of the earth' (King James Version), translating the Hebrew words peri ha-aretz in Isaiah 4:2. Remarkably, Moltmann (2012:155) refers to this phrase in Isaiah and confirms that it is a name given to the Messiah. He says that the words from the Lord's Prayer, 'on earth as it is in heaven' (Mt 6:10), attest to God's concern for 'his beloved 
earth' and 'really and truly mean the earth'. The name Fruit of the land points to a 'salvific mystery' of the earth and the land:

The earth (land) is not only the mother of all the living; in this perspective, it is also 'the womb of God', that is to say, the mother of the Saviour and of salvation. (Moltmann 2012:155) ${ }^{3}$

Around AD 250, the Letter of Barnabas already taught that our Lord Jesus became earth or land (Greek: gé), as he became man (Greek: anthropos), and man was made from soil. In this way, Jesus is also the fulfilment of the land flowing with milk and honey (Barnabas 1912:6.8). 'For Christianity, the earth's mystery of salvation is the cosmic Christ' (Moltmann 2015:82). Friendship with Jesus implies friendship with the earth and the soil of the land (cf. Moltmann-Wendel 2000:32, 112). The Logos [Christ] is the Firstborn (Greek: Prototokos) of all creation (Col 1:15); therefore, 'there is also a resonance of God in all creation' (Bavinck 1961:13, [author's own italics]).

The resurrection of Christ includes the bringing of 'the first anticipatory radiance of immortal being to mortal creation' (Moltmann 1990:253) and thus also to the land. According to a significant observation by the Afrikaans reformed theologian, W.J. Snyman (1977), it can be stated that:

\begin{abstract}
... the first seven chapters of the book of Isaiah - those very chapters including the prophecy traditionally interpreted as relating to the virgin birth of Christ (chapter 7 verse 14) - are governed by the thought of the land and its fruits and the Fruit of the land, and (they) must be read in this light. Christ is the Sprout, the Fruit of the land. The Child who was born is from heaven. But He was born from a woman ... He had his birth-soil, his fatherland, his mother tongue ... (p. 496)
\end{abstract}

In the perspective of this investigation, it is furthermore important to emphasise the eschatological horizon of the sighing creation, including the groaning of land and soil ( $R m$ 8:22). Here, it does not seem illegitimate to 'draw on our knowledge of the way human greed has intensified creation's groaning' (Southgate 2008:1). Yet, in a paradoxical way, this horrible and culpable intensification through human sin might be 'used' by the cosmic Creator Spirit as an addition to the 'sufferings of an all-embracing divine dynamic', manifested as the birth pangs of the freedom-world of God's children. Indeed, 'when freedom is near, the chains begin to chafe' (Moltmann 2010:206-207). 'All things' (Greek: ta panta) in heaven and on earth that God will gather together under one Head (Greek: anakephalasasthai), namely Christ, can be interpreted as 'all created things' (Eph 1:9, 10). Thus land is included in this universal task of Christ.

Against this background of an eschatologically motivated 'deep incarnation' (Deane-Drummond 2009:107, 128-155, 216), the Messianic name Fruit of the land undoubtedly receives a poignant relief. Incisively, Snyman (1977) argues that our Lord Jesus Christ is:

3.It is ironical that: the very word 'matter', on which materialism is based, comes from the Latin materia, from the word for mother, mater ... Materialism is not solely a philosophical theory. Below the surface, it is an unconscious cult of the Great Mother (Sheldrake 2017:83-84).
The Fruit of the land, the Grain of Wheat who dies, not to stay alone, but to bear fruit (Jn 12:24; Is 53:10), the first fruit of those who have fallen asleep (1 Cor 15:20). The land is then really an acre of death, where it is sown in perishability and raised in imperishability ... (1 Cor 15:42,43) ... it is not so that the promise added to the Fifth Commandment ('that you may live long in the land the Lord your God is giving you') has been annulled in the New Testament. In the light of the fulfilment, it has become: for ever. (p. 497, [author's own italics])

Santmire (2000:127) even relates the thinking about our promised 'intimate communion with the whole earth' to Calvin's strange and guarded statement (Inst. 1.5.5) 'that the expression "Nature is God" may be piously used if dictated by a pious mind'. Is it not possible that the Spirit might lead us by means of such unusual modes of thinking into some forgotten accents of truth (cf. Santmire 2000:127)? This does not mean inventing new truths, 'but all that Jesus taught and did, He (the Spirit) will manifest in a new light, in a new age, in the face of new situations and new experiences' (Küng 1980:28).

To summarise: this subsection argues that, for Christians, the inner drama of commerce with Christ as the Fruit of the land will influence how commercial dealings in land distribution might be brought into play today.

\section{The external drama: Eucharistic communion}

Besides an inner drama of sharing in the sancta, there also exists an external drama of communion, namely the Eucharist in which Christ, according to Calvin (Inst. 4.17.3; 4.17.7), presents a 'complete attestation ... that He accomplishes inwardly which he externally designates'. Against the background of the ancient adagium, lex orandi, lex credendi [the law of praying is the law of believing], Moore-Keish (2008:92) draws attention to the 'curious resonance' with contemporary ritual research that she detects in Calvin's embodying of words in Eucharistic performances. The resonances might even become stronger when these 'ritual' embodiments are related to 'the organizing metaphor in Calvin's thought' (Lane 2011:59), namely the theatrical (cf. above: dramatic actions as synthesis of the epic and the lyric).

In his commentary on Psalm 138:1, for example, Calvin views the liturgical gathering of the church 'quasi celeste theatrum est' [as if it is a celestial theatre] (cf. Selderhuis 2000:217 for the source of this quotation). The Eucharist, says Wright (1999:66), 'is indeed a play, the greatest drama ever staged'. Accommodating some insights from the Roman Catholic theologian, Ratcliffe (2008:7), we might portray the Lord's Supper 'as a drama in three acts through which we share God's life and begin even now to be touched by God's happiness. Each act prepares for the next'. Act 3 forms the apex of this sacred drama as reached in the four ritual enactments of the communion with the sacra itself (blessing, breaking of bread, sharing and eating), followed by the Eucharistia [thanksgiving] and Missio [mission] to the world. 
It is the central communion dynamic of giving, receiving and eating in Act 3 of the Eucharistic drama (cf. previous paragraph) that is of most importance for our inquiry. Notably, it is not the breaking of the bread and the pouring of the wine as rituals that should be regarded as sacramental 'gates' (cf. Calvin 1975:118; Wallace 1997:23) to the communion with Christ. To regard the Eucharist as a 'passion play' in which the passion and death of our Lord is re-enacted (cf. Berkouwer 1954:287), would be a gross misunderstanding of our intention. However, what is 'played with joy', especially in these central actions of the Eucharist, is the very communion with Christ (Van Ruler 1970:85).

At this 'spiritual table', we enact the feast of the Kingdom by receiving earthly and visible (broken) bread and (pouredout) wine, and 'hold this in our hands and eat and drink the same with our mouths', convinced by the Word and Spirit that we are in reality being given, taking and eating the 'proper and natural body and the proper blood of Christ', but by 'faith, which is the hand and mouth of our soul' (Belgic Confession 1561:35). We act out this unfathomable sacramental mystery of receiving this communion and thus strengthening the unio mystica with Christ as 'members of his flesh' (membra ex carne eius) (Wallace 1997:151, quoting Calvin's comments on 1 Cor 11:24), fully knowing that this flesh is the crucified and glorified flesh 'given for the life of the world' (Jn 6:51). ${ }^{4}$ In this sense, it can be said that the Eucharist is faith, hope and love's 'dress rehearsal' (Norris 1999:94) of the coming marriage feast of the Lamb for the whole cosmos.

\section{The Fruit of the land and bread and wine}

Within the 'playful excessiveness' (Pannenberg 1986:47), expressed in the sacramental communion of the sacra, namely with Christ who is also the Fruit of the land and his benefits, it is imperative for this inquiry to emphasise that this communion makes us partakers of his life within the concreteness of land - also in South Africa today. Already in the 2nd century, the Church Father, Irenaeus of Lyon (1920), affirmed that the incarnated Logos of God, Christ, is:

\footnotetext{
... in unseen wise in our midst (and) is universally extended in all and encompasses its length and breadth and height and depth ... in it (the world) is crucified the Son of God, inscribed crosswise upon it all ... (p. 49, par. 34)
}

The Lord of the land is inscribed crosswise not only upon the land in which we share by virtue of our unio mystica with Christ, but also upon the bread and the wine that are employed as 'props' (Vanhoozer 2014:160) for the Eucharistic enactment. This 'broken bread [was indeed] scattered across the mountains [and made] one after it had been gathered', according to chapter 11 of the Didache, written in about AD 100 (Pretorius 1980:21). Microcosmically, communion through these cruciform Eucharistic elements represents the world, including land, in a dense form, 'as it ought to be'

4. There is no reason to take either the notion of world or that of life in a limiting sense. Not only of humans and their world we should here think, but all life that there is in the whole world relates in its existence, maintenance and full evolving to Christ's reconciliatory work (Greydanus n.d.:71).
(Leithart 2000:153). This world as it should be, the Kingdom of God, is thus a sphere of 'bread-eaters' and not of spiritualised people elevated above the status of material creatures (cf. Leithart 2000:168).

This is the very material bread probably referred to in the prayer for 'our daily bread' or for the 'bread of tomorrow' to be given to us today (artos epiousios); it becomes 'Eucharistic food ... only in relation to the risen Christ who is the firstborn from the dead' (Col 1:18; Rv 1:5; Zizioulas 2011:25). By eating from that fruit of the land (bread and wine) through faith, we act out the 'wonderful exchange' with him who is the Fruit of the land and also the First Fruit of the coming new earth so that we, who have no claim on God's earth, can hand over to him our restless desire for land. Out of his abundance, God permeates us then through the Spirit with a foretaste of our inheritance of earth and land as they will gloriously persist in the coming Kingdom of God (Mt 5:6). Rightly, Van Ruler (1973:70) comments that this Kingdom word of Jesus 'indeed results in love for the earth (land)'. Thus, love is part of the deep communion, the mystery of the 'commerce' we have with the land in Christ.

The theodrama of being companions-partakers in the sancta of bread and wine ('companion' derives from Latin cum [with] and panis [bread] - a 'with-bread-ness') certainly includes the earth. In the creation story, the earth 'produced' or 'brought forth' (Gn 1:12; Hebrew: tocee); furthermore, 'all by itself, the soil produces corn' (Greek: karpoforei) (cf. Moltmann-Wendel 2000:114-115). Land is not a dead commodity to be stolen, bought or sold disrespectfully, used and misused as a 'soulless' thing (cf. Scruton 2014:passim). To the contrary, it is quickened and saturated by that deep, interactive sharing that the cosmic Christ and the cosmic Spirit provide:

The Bible does not view land as simply an inert object, a thing upon which humans act. Rather it is a living creature, a community of creatures with its own capacity to respond to its Creator. Humans are meant to 'serve' the land, to foster a healthy relationship between it and God. (Davis 2015:2)

\section{Comedy of the sancti}

\section{A prelude of liberty, equality and brotherhood}

'The church dares to celebrate the feast and, at the table, (to) enact the "play" of the future, the liberty, equality and brotherhood of the coming Kingdom of God' (Berkhof 1986:367). This daring play stirs through the prompting of the Holy Spirit our imagination of how this freedom, equality and brotherhood might be improvised (not merely repeated from its performance in a previous act of God's kingdom play) precisely in this enfolding stage of the Penultimate Act in which we are between 2015 and 2020. In the ecclesial Eucharist, believers 'take part' in the 'sacrament as a "holy thing" by being in that very act partakers of each other as "holy persons"' (cf. Van Ruler 1969:146).

The "great biblical image of the "outpouring of the Spirit"' (Welker 2017:19) might throw more light on the actors and 
their talents in this comedy of the sancti, probably nowhere better than in the well-known Pentecostal 'scene' at the beginning of the Penultimate Act of the kingdom drama (Ac 2; cf. Bartholomew \& Goheen 2004:174-175) in which a 'close-up' of the dramatic event, unleashed by the outpouring of the Spirit, becomes visible.

The Spirit of Christ, the resurrected Crucified, energises fearful, servile men and women to become wonderfully free (cf. Ac 4:13; note the Greek word parrésia). Secondly, the Holy Spirit energises them to become totally equal in their receiving of the Spirit's outpouring of his gifts (Ac 2:17, 18): old men and women, and slaves, both men and women. Thirdly, 'people from many nations, many cultures, and many languages are overcome by the Spirit of God' and thus all ethnocentrism and tribalism are undermined in a new brotherhood (cf. Welker 2017:18; cf. Gl 3:26-29). Something of what Calvin (Inst. 2.20.23, with reference to Eph 3:10) perceived as 'God's theatre' of 'manifold wisdom' shines through this paradigmatic commerce of the sancti while the end drama of 'this passing age' (1 Cor 7:31; cf. Calvin 1972:131 where, in this text, he finds an allusion to the split moment in a dramatic production when the 'curtains are drawn away' to begin 'another' act - theodramatically understood - the Grand Finale) was inaugurated. In this theatre, the manifold gifts are spread out across all actors, calling every actor according to his or her specific gifts to a participation in the play (cf. $1 \mathrm{Pt} \mathrm{4:16).} \mathrm{Indeed,} \mathrm{the} \mathrm{charisms} \mathrm{[gifts]} \mathrm{of} \mathrm{the} \mathrm{actors}$ are 'talents with which the Spirit plays' (Schoonenberg 1985:47) - also on the 'stage' of land tenure.

\section{Permeating the sancti's actions of land reform}

Drawing on the deep internal and external enacting of our commerce with the sancta, the play of freedom, equality and brotherhood should not find its outer limit merely in the Eucharist, but should overflow and broaden out into the frustrating secularist context of land contests. Emphatically stated, we are not talking about performing a kind of liberalistic, modernistic and idealistic commerce between atomistic individuals. Freedom, equality and brotherhood were 'for a long time taken as slogans of the devil ... [yet they] have a foundation in earliest Christianity' (Küng 1995:733) and should be 'redeemed' with respect to its true biblical resonance (cf. Ward 2010:17-21). An attempt at such 'redemption' is the present effort to integrate them into the repertoire of a theodramatic 'company' (cum plus panis) of actors who are broken (such as the broken Eucharistic bread), but who are, as such, playing out a cruciform, fragmentary prelude of the coming freedom, equality and brotherhood as is already now being choreographed by the Holy Spirit.

Remarkably, Paul also includes 'the genitals' as referent in his inspired depiction of what we call a 'comedy of commerce' in the way he fills in his picture of the sancti forming the body of Christ: 'and the parts that we think are less honourable we treat with special honour' (1 Cor 12:23). Ward (2009:253) can remark that 'any possible democratization in terms of equality' has to mirror itself in the 'new politics of living in Christ'. No discrimination based on status, whether received by any political majority rule or racial, sexual and inherited dominance, has a place in a communion thus created by the Spirit. In 1 Corinthians 12:23 the Greek word schema [dress, form, manner, dignity, demeanour] constitutes the root of ta aschémona [literally: the undressed, undignified] and euschémosunén [literally: well-dressed, dignified]. Therefore, Calvin (1972:216) can elegantly comment that the meaning of the last part of the text is: 'putting on a covering for beautification, in order that the members who visibly seem ugly, might be dressed honourably'. This is extremely relevant in our situation of land reform. On one hand, this brings hope for, particularly, sancti who today still feel - or are perhaps made to feel - aschémena in Christ's body. The assessment to be inferior or in some cases even sub-human, according to a 'racial calculus', have been mainly engendered by Christian European colonialism (but also 'apartheid') who, in a kind of missionary zeal focused on 'inscribing native bodies in the drama of redemption's journey, a journey marked by easy paths (white bodies) and rough terrain (black bodies)' (Jennings 2010:36). In kingdom perspective, they should today be treated as totally euschémosunén - with the same respect as, and equal co-actors of, the other role-players in land reform. On the other hand, sancti who feel - or are perhaps made to feel - politically disempowered and thus aschémata through majority democratic hegemony, must also be treated as dignified and equally respected members.

\section{Impacting civil communities engaged in land reform}

The enactment by the sancti as church members amid alternative dramatic versions of land reform (cf. above) must, by nature of the kingdom horizon in which it takes place, challenge all non-religious or alternative religious groups that are active in land reform. In this regard, not only the secular state must come into focus, but we argue that especially 'communities' in civil society should be drawn hospitably into the Spirit-prompted comedy of commerce. In his brief exposition of what the communion of the sancti (according to the HC, 21:55) entails, Barth (1964:87) does not limit the mutual sharing of the sancti's benefits merely to the church internally. He detects a universal scope in this confession. It is 'in this way', namely by serving each other as members, that the sancti 'serve the benefit and welfare of all men' (Barth 1964:87; [author's own italics]). The question to be faced, then, is how the broken ecclesiastical prelude of communion, manifested in an admirable commercium, might be extended into communities performing acts of such or comparable commerce on the wider stage of land apportionment.

The well-known Lutheran theologian, Pannenberg, contends that the way in which, 'from the centre of the Christian faith outwards, preliminary and always revisable models for the renewal of societal systems ...' might be pursued, is rather in the 'by far more productive' mode of Calvinistic societal thinking than, for example, in a Lutheran context (Pannenberg 1986:66). Importantly, he refers, inter alia, to the resemblance 
Calvin sees between the sanctorum communio and the worldly regiment for the reason that the latter also 'needs a charismatic leadership and giftedness by the Spirit of God' (Pannenberg 1986:68 referring to Krusche 1957:110). Yet, Calvin seemingly hesitated to draw out the full consequences of this confession for civil life. Surely, he does teach that all the God-given blessings of this communion are to be 'mutually communicated to each other', but, at the same time, he limits this mutuality of God-given communion blessings by juxtaposing it to an imperative of peaceful civil society, namely 'that distinct rights of property should exist' among men (Inst. 4.1.3, [author's own italics]).

Although Acts 5:4 supports this view, it seems as if the 'restraint' of Calvin regarding the application of the communio confession (Noordmans 1954:201) was exacerbated by his fulmination against the 'outrageousness' of the Anabaptists who advocated a revolutionary implementation of this article in the society of his day (pp. 200-201). Nevertheless, Calvin's 'hardness' (Noordmans 1954:201), in not generously drawing out the consequences of this rich 'communion' into general civil life, including property issues, resulted in a marked reticence of the later Calvinistic world to think through the full potential of this communion for the reformation of capitalistic property theories. The critique of Noordmans (1954:201) should thus be heeded earnestly par excellence in the land issue today: 'Public justice then came into sharp contradiction with the justice of the Kingdom of heaven and with the church of the Apostolicum.'

\section{Concluding viewpoints \\ 'Theatrically' emphasising the 'doing' of a confessional truth}

Realising that our land problems are extremely relative in comparison with world history, which, already from pre-historical times on (cf. Armstrong 2014:10-110) had experienced many violent land conflicts, we might at least learn a little humility in land-reform:

God gave us a place as if in a theatre, in order that we should transit not only a short span of time like hundred or more years but in order that we should encompass the whole world history, and certainly not as dumb spectators but as people that in the most intimate manner engaged therein, always willing to learn and make applications for our teaching from this theatre. (Calvin in Sermon no 31 from Job as quoted by Van 't Spijker 1977:85, [author's own italics])

This forms the broadest horizon for us theologically, bringing to bear Article of the Apostolicum, namely communio sanctorum on the concrete, quotidian and controversial question of land reform, especially in South Africa. The investigation was launched, not only in the more traditional perspective of a faith, confessed with the heart and the mouth (cf. for example Belgic Confession 1561: Art. 1: 'we believe all with the heart and confess with the mouth ...'). Akin to the Hegelian notion of Aufhebung, this contribution rather probes a more widelensed approach - although narrower than Calvin's world theatrical lens (cf. above) - to the Ninth Article of the
Apostolicum, namely as if that Article is part of a 'script' for a faith drama. It digested, from the 'canonical script', the Bible in all its diversity of God-breathed (theopheust) genres and utterances. This way of 'reframing' (cf. Zizek 2014:7-32) does not mean that the reality of what we confess as communio sanctorum is changed into a fictional 'as if' (cf. Antlitz 2017:3-4). The reality of that communion is merely viewed through a lens that is sharper and more emphatically than other focuses on the 'doing' of confessional truth (cf. putting Jesus' words 'into practice' - Mt 6:24; 'walking in the truth' 2 Jn:3). Thus, we might speak of 'faith seeking conscious enactment or improvisation of a script', and this includes 'faith seeking understanding'. Seen within such dramatic metaphorical framework, the gist of this communion is enacted as a 'comedy of commutatio mirifica' [wonderful commerce/exchange]. The term comedy does not denote an idealistic make-believe farce, but a hopeful Christian enactment (cf. Leithart 2006:136-137), incorporating also the

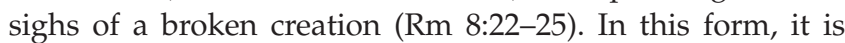
imaginatively looked at as opposing the anangké or fateful despair of a Greek-style tragedy. It is exactly as if they perform a counter-drama-enacting-Kingdom-dynamic ('the kingdom of God is not a matter of talking - en logoi - but of power - en dunamei' -1 Cor 4:20), which the dramatis personae have to play out communio sanctorum in land reform. In other words, it is as if a specific embodiment of kingdom-dunamis is dramatically enacted in the public, political and social amphitheatre of land reform and thereby specifically confronting alternative 'dramas' based on ideological 'scripts' of land reform, which, according to the first-mentioned view, can only be human, economic and ecological tragedies (either embodying inordinate, or even exorbitant claims of the landless or of the land-owners). This 'tragedy' is seen as being biblically prefigured in the idolatrous greed of the 'Rich Fool'.

\section{Towards concretising the argument}

Two examples of concretising the above argumentation are briefly given: one from - metaphorically speaking - the 'Third Act' of God's kingdom-drama (the New Testament, which is also part of the Divine Play's 'script-formation'); and the other a practical illustration from our own 'Penultimate Act'.

Practical advice from Paul: On the one hand then, in 'one of the most remarkable economic statements of the New Testament', namely 2 Corinthians 8 and 9 (cf. Ford 1997:123), Saint Paul gives 'directives' to Corinthian Christians for 'proving' their verbal and heartfelt confession of koinonia by practically acting out their confessed sharing with the poor Christians of Jerusalem and with anyone else (2 Cor 9:13). Without doubt, Paul's 'advice' - not 'command' (2 Cor 8:8, 10) might, mutatis mutandis, also be applied to present inequalities in land-tenure. Central is the apostle's appeal to the graceful exchange or commerce made by our rich Lord in becoming 'poor for your sakes, so that you through his poverty might become rich' (2 Cor 8:9). Seen through the lens of drama, which we have espoused in the above discourse, the effect of believers' participation in this 'taking-givingreceiving-enactment' is 'setting in motion a chain-reaction' 
(Ford 1997:122) of koinonial sharing displayed in their material, economic goods commerce with their needy and economically unequal 'co-actors' in Jerusalem:

The gift is acceptable according to what one has, not according what he has not ... our desire is not that other might be relieved while you are hard-pressed but that there may be equality (isotétos). (2 Cor 8:12,13)

To summarise: according to this canonical 'advice', confessional-communal sharing in land reform does not mean that the 'haves' should enact a 'straight line of altruistic giving' (Leithart 2012:2) to the 'have nots'. 'Paul offers something more interesting. In the church, gifts ... move in a circle, but the circle expands infinitely because God begins the giving by giving his Son' (Leithart 2012:2).

The Missio Dei foundation (MD Foundation): On the other hand, a contemporary practical initiative (only one of more) that could exemplify the argument of this proposal, is the work being done by the MD Foundation with headquarters and central hub of activity near Ficksburg, Free State, South Africa. A 'non-white' journalist whose father's remark in the mid-1990s that 'the only good boer is a dead boer' had lodged itself in his memory, admits that this Foundation was one of the farmer communities who helped him change his mind, inter alia, about land reform (Price 2018:2). Of course, this Foundation does not theologise about itself through the epistemic lens of theodrama. Yet, our conviction is that it forms an eminent enactment of the communio sanctorum, which we not only envisage, but also in land reform. The beginnings of this Foundation reaches back to 2010, with a faith vision 'to make God's Kingdom visible on earth by being faithful stewards' in certain fields of concrete action (MD Foundation 2018):

Farmers decided to give all their possessions (including land) to form a company where they (former land owners and former landless) can farm together effectively while serving the (multiracial and multi-cultural) community and create practical models that can provide answers to the challenges we are facing today in South Africa (in 2019 this Foundation is continuing to flourish, by the grace of God). (p. 1; cf. Price 2018:2)

\section{Acknowledgements \\ Competing interests}

The author declares that he has no financial or personal relationship(s) which may have inappropriately influenced him in writing this article.

\section{References}

Antlitz, K., 2017, 'Metaphor matters: An apology for theodrama', Transpositions, viewed 27 February 2019, from https://www.bing.com/search?q=metaphors+ matter ++ Transpositions8cform $=\mathrm{EC}$.

Armstrong, K., 2014, Fields of blood: Religion and the history of violence, The Bodley Head, London.

Bakker, J.T., 1978, 'In Christus: Verzoening als levensvorm', in H.H. Grosheide, J.C. de Moor, C.J. den Heyer (reds.), De knechtsgestalte van Christus: Studies aangeboden aan prof. dr. H.N. Ridderbos, pp. 34-46, Kok, Kampen.

Barnabas (ca. AD 250), 1912, 'Epistle of Barnabas', in K. Lake (ed.), pp. 1-19, The apostolic fathers, Heinemann, London.
Barth, K., 1964, Learning Jesus Christ through the Heidelberg Catechism, transl. S.C. Guthrie, Jr., Eerdmans, Grand Rapids, MI.

Bartholomew, G. \& Goheen, M.W., 2004, The drama of Scripture: Finding our place in the biblical story, Baker Academy, Grand Rapids, MI.

Battles, F.L., 1984, 'God was accommodating himself to human capacity', in D.K. McKim (ed.), Readings in Calvin's theology, pp. 21-40, Baker, Grand Rapids, MI. Bavinck, H., 1961, Welsprekendheid, vert. S.P. van der Walt, Pro Rege, Potchefstroom. Bavinck, H., 1968, De katholiciteit van Christendom en kerk, Kok, Kampen.

Beker, E.J. \& Hasselaar, J., 1990, Wegenenkruispunten in de dogmatiek, vol. 5, Kok, Kampen.

Belgic Confession, 1561, De Nederlandse Belijdenisgeschriften, in authentieke teksten, met inleiding tekstvergelijkingen door J.N. Bakhuizen van den Brink, Ton Bolland, Amsterdam.

Berkhof, H., 1959, 'De gereformeerde catholiociteit en de liturgie', in W.H. Beekenkamp (red.), Ecclesia: Een bundelopstellen aangeboden aan prof. Dr. J.N. Bakhuizen van den Brink, pp. 214-225, Kok, Kampen.

Berkhof, H., 1986, Christian faith: An introduction the study of the faith, transl. S. Woudstra, rev. edn., Eerdmans, Grand Rapids, MI.

Berkouwer, G.C., 1949, Geloof en rechtvaardiging, Kok, Kampen,

Berkouwer, G.C., 1954, De sacramenten, Kok, Kampen.

Berkouwer, G.C., 1970, De Kerk Deel 1: Eenheid en katholiciteit, Kok, Kampen.

Brueggemann, W., 1989, Finally comes the poet: Daring speech for proclamation, Fortress, Minneapolis, MN.

Brueggemann, W., 1993, Biblical perspectives on evangelism: Living in a three-storied universe, Abingdon, Nashville, TN.

Buitendag, J., 2009, 'Triniteit en triangulasie: Op soek na 'n kosmiese liturgie', in F.G. Immink \& C. Vos (reds.), God in 'n kantelende wêreld, pp. 220-230, Protea, Pretoria.

Calvin, J., 1962a, Johannes Calvin's Lebenswerk in seinen Briefen: Eine Auswahl von Briefen in deutscher Uebersetzung von R. Schwarz, Zweiter Band, Neukirchener, Neukirchen.

Calvin, J., 1962b, Institutes of the Christian religion, vol. 1 \& 2, transl. H. Beveridge, James Clarke, London.

Calvin (Calvijn), J., 1972, Uitlegging op de Eersten en Tweeden Zendbrief van Paulus aan de Corinthiërs, naar de uitgaven van de Oude Hollandsche oversetting van J.D., in de tegenwoordige spelling door A.M. Donner, De Groot, Goudriaan.

Calvin, J., 1975, Genesis, transl. J. King, Banner of Truth, Edinburgh.

Cavanaugh, W.T., 2008, Being consumed, Eerdmans, Grand Rapids, MI.

Changuion, L. \& Steenkamp, B., 2012, Disputed land, Protea, Pretoria.

Conradie, E.M., 2013, Saving the earth: The legacy of reformed views on 're-creation', LIT, Wien.

Cousins, B. \& Hall, R., 2017, 'South Africa is still way behind the curve on transforming land ownership', The Conversation, 13 November, pp. 1-3.

Cousins, B. \& Hall, R., 2018, 'South Africa's land debate is clouded by misrepresentation lack of data', The Conversation, 8 March, pp. 1-4.

Davis, E.F., 2009, 'Propriety and trespass', in S.C. Barton \& D. Wilkinson (eds.), Reading Genesis after Darwin, pp. 204-216, Oxford University Press, Oxford.

Davis, E.F., 2015, 'Wisdom knows its place', viewed 4 April 2018, from www.biblesociety.org.uk/.../Shangai-EDavis.pdf.

Deane-Drummond, C., 2009, Christ and evolution, Fortress, Minneapolis, MN.

Eco, U., 2007, Turning the clock back: Hot wars and media populism, Sacker, London.

Ford, D.F., 1997, The shape of living, Harper, London.

Ford, D.F., 2011, The future of Christian theology, Wiley-Blackwell, Oxford.

Ford, D.F., 2014, The drama of living: Becoming wise in the Spirit, Canterbury Press, Norwich.

Gerrish, B.A., 1993, Grace and gratitude: The eucharistic theology of John Calvin Augsburg Fortress, Minneapolis, MN.

Goosen, D., 2009, Die nihilisme: Notas oor ons tyd, PRAAG, Pretoria.

Goosen, D., 2015, Oor gemeenskap en plek: Anderkant die onbehae, FAK, Pretoria. Greydanus, S., n.d., Schriftoverdenkingen, ingeleid door C. Veenhof, Kok, Kampen.

Hegel, G.W.F., 1973, Hegel's lectures on aesthetics, part C, section 3, chapter 3D, 1A, transl. M. Knox, viewed 4 April 2018, from https://www.marxists.org/reference/ archive/hegel/works/ae/part3-section3-chapter3.ht.

Hobson, T., 2009, Faith, Acumen, Durham.

Horton, M., 2002, A better way: Rediscovering the drama of God-centred worship, Baker, Grand Rapids, MI.

Horton, M., 2011, Christian faith: A systematic theology for pilgrims on the way, Zondervan, Grand Rapids, MI.

Inst. see Calvin 1962b

Irenaeus of Lyon, 1920, The demonstration of the apostolic preaching, transl. A. Robinson, The Macmillan Co., New York.

Jennings, W.J., 2010, The Christian imagination: Theology and the origins of race, Yale University Press, New Haven, CT.

Jüngel, E., 1988, The freedom of a Christian: Luther's significance for contemporary theology, transl. R.A. Harrisville, Augsburg, Minneapolis, MN. 
Käsemann, E., 1980, Commentary on Romans, transl. G.W. Bromiley, Eerdmans, Grand Rapids, MI.

Knott, M.L., 2015, Unlearning with Hannah Arendt, transl. D. Dollenmayer, Granta, London.

Krusche, W., 1957, Das Wirken des Heiligen Geistes nach Calvin, Vandenhoeck Göttingen.

Küng, H., 1980, The church - Maintained in truth: A theological meditation, transl. E. Quinn, SCM, London.

Küng, H., 1995, Christianity, transl. J. Bowden, SCM, London.

Lane, B.C., 2011, Ravished by beauty, Oxford University Press, Oxford.

Leithart, P.J., 2000, Blessed are the hungry: Meditations on the Lord's Supper, Canon, Moscow, ID.

Leithart, P.J., 2006, Deep comedy: Trinity, tragedy and hope in Western literature, Canon, Moscow, ID.

Leithart, P.J., 2012, 'Christmas as heavenly economy', First Things 12(21), 1-3.

MD Foundation, 2018, 'This is the story of the people of MD Foundation', viewed 4 April 2018, from https://demo55.linux-hosting.hosting.co

Modise, L. \& Mtshiselwa, N., 2013, 'The Native Land Act of 1913 engineered the poverty of Black South Africans; A historico-ecclesiastical perspective', paper read at the Conference of TSSA, Cape Town, June, viewed 4 April 2018, from uir.unisa. ac.za/bitstream/handle/10500/13143/Modise-Mtshiselwa.pdf?sequence=1

Moltmann, J., 1990, The way of Jesus Christ, transl. M. Kohl, SCM, London.

Moltmann, J., 1991, Der Geist des Lebens: Eineganzheitliche Pneumatologie, Kaiser, München.

Moltmann, J., 2000, Experiences in theology: Ways and forms of Christian theology, transl. M. Kohl, SCM, London.

Moltmann, J., 2010 Sun of righteousness arise! God's future for humanity and the earth, transl. M. Kohl, Fortress, Minneapolis, MN.

Moltmann, J., 2012, Ethics of hope, transl. M. Kohl, Fortress, Minneapolis, MN.

Moltmann, J., 2015, The living God and the fullness of life, transl. M. Kohl, Westminster John Knox, Lousville, KY.

Moltmann-Wendel, E., 2000, Rediscovering friendship, SCM, London.

Montanari, L., 2018, 'Fight rages over land reform in South Africa', viewed 4 April 2018, from https://www.Montanari[2018/03/14]/fight_rages_over_land_refForbes. com/sites/lorenzo.

Moore-Keish, M.L., 2008, Do this in remembrance of Me: A ritual approach to reformed eucharistic theology, Eerdmans, Grand Rapids, MI.

Ngcukaitobi, T., 2018, The land is ours: South Africa's first black lawyers and the birth of constitutionalism, Penguin Random House, Cape Town.

Noordmans, O., 1954, Het koninkrijk der hemelen: Toelichting op de Heidelbergse Catechismus, deel 2, Wever, Franeker.

Norris, R.A., Jr., 1999, 'The eucharist in the church', in C.E. Braaten \& R.W. Jenson (eds.), Marks of the body of Christ, pp. 83-94, Eerdmans, Grand Rapids, MI.

Pannenberg, W., 1986, Christliche Spititualität, Vandenhoeck, Göttingen.

Piper, J. \& Mathis, D. (eds.), 2010, With Calvin in the theatre of God: The glory of Christ and every-day life, Crossway, Wheaton, III.

Pretorius, N.F., 1980, Die Didache, NGK, Pretoria.

Price, I., 2018, 'Bou met boere', Kuier-tydskrif, 2018/06/31, viewed 25 February 2019 from https://www.netwerk24.com/Kuier/mening-bou-met-boere-20180831815 AutoPul.

Ratcliffe, T., 2008, Why go to church? The drama of the eucharist, Continuum, London Rijnsdorp, C., 1954, In drie etappen, Bosch, Baarn.

Robinson, M., 2016, 'Theology for this moment', Svensk Teologist Kvartalskrift 62(3\&4) 141-147.
Santmire, H.P., 2000, Nature reborn: The ecological and cosmic promise of Christian theology, Fortress, Minneapolis, MN

Schoonenberg, P., 1985, 'Charismata, talenten waar de Geest mee speelt', in J.A. van der Ven (red.), Toekomstvoor de kerk? Studies voor Frans Haarsma, pp. 47-58, Kok, Kampen.

Scruton, R., 2014, The soul of the world, The Princeton University Press, Princeton.

Selderhuis, H.J., 2000, God in het midden: Calvijns theologie van de Psalmen, Kok, Kampen.

Sheldrake, R., 2017, Science and spiritual practices, Coronet, London.

Snyman, W.J., 1977, Nuwe en ou dinge uit die skat van die Koninkryk, Pro Rege, Potchefstroom.

Southgate, C., 2008, 'The groaning of creation', viewed 4 April 2018, from www.joh. cam.ac.uk/index.php?q=system/files/sites/defaults/files.

Terreblanche, S., 2014, Western empires, Christianity, and the inequalities between the West and the East (1500-2010), Penguin, Cape Town.

Torrance, J.B., 1996, Worship, community and the triune grace of God, Carlisle, Paternoster.

United Nations, 1973, UN Convention on Apartheid as a crime against humanity, viewed 4 April 2018, from www.politicsweb.co.za/documents/1973-un-convention-onapartheid-as-a-crime-against-humanity.

Van der Kooi, C., 2002, Als in een spiegel: God kennen volgens Calvijn en Barth, Kok, Kampen.

Vanhoozer, K.J., 2005, The drama of doctrine: A canonical-linguistic approach to Christian theology, WJK, Louisville, KY.

Vanhoozer, K.J., 2014, Faith speaking understanding: Performing the drama of doctrine, WJK, Louisville, KY.

Van Onselen, G., 2015, Holy cows: The ambiguities of being South African, Tafelberg Cape Town.

Van Ruler, A.A, 1969, Ik geloof: De Twaalf Artikelen van het geloof in morgenwijdingen, Callenbach, Nijkerk.

Van Ruler, A.A., 1970, Waarom zou ik naar de kerk gaan? 2e druk, Callenbach, Nijkerk.

Van Ruler, A.A., 1973, Laat heel de aarde en loflied wezen, Callenbach, Nijkerk.

Van 't Spijker, W., 1977, Reformatie en geschiedenis, Oosterbaan, Goes.

Van 't Spijker, W., 1995, Gemeenschap met Christus: Centraal gegeven van de gereformeerde theologie, Kok, Kampen.

Veltkamp, H.J., 1988, Pastoraat als gelijkenis: De gelijkenis als model voorpastoraa handelen, Kok, Kampen.

Versteeg, J.P., 1987, Hogeronderwijs: Bijbeloverdenkingen, Kok, Kampen.

Ward, B.K., 2010, Redeeming the Enlightenment: Christianity and the liberal values, Eerdmans, Grand Rapids, MI.

Ward, G., 2009, The politics of discipleship: Becoming postmaterial citizens, Baker Grand Rapids, MI.

Wallace, R.S., 1997, Calvin's doctrine of the Word and Sacrament, Wipf, Wugene, OR.

Welker, M., 2017, 'Holy Spirit and human freedom: A John Paul II Memorial Lecture', International Journal of Orthodox Theology 8(1), 9-13.

Wolterstorff, N., 2011, Hearing the call: Liturgy, justice, church, world, Eerdmans, Grand Rapids, MI.

Wright, N.T., 1999, The meal Jesus gave us: Understanding Holy Communion, Hodder, London.

Zizek, S., 2014, Event, Penguin, London

Zizek, S., 2017, The courage of hopelessness: Chronicles of a year of acting dangerously, Penguin, London.

Zizioulas, J.D., 2011, The eucharistic communion and the world, Clark, London. 